\title{
PERADABAN: PRIBUMI
}

Oleh Shohibul Anshor Siregar

Ketika melakukan penggambaran tentang karakteristik politik umat Islam Indonesia, Eep Syaifullah Fattah memberi 25 deskripsi rinci yang jika ditelaah tentulah hal-hal negatif itu tidak terbentuk dengan sendirinya. Sejarahnya sudah panjang sekali. Umat Islam Indonesia senang membuat kerumunan, tidak rajin menggalang barisan. Suka marah, tidak suka melakukan perlawanan. Reaktif, bukan proaktif. Suka terpesona oleh keaktoran, bukan oleh wacana atau isme yang dimiliki/diproduksi sang aktor. Sibuk berurusan dengan kulit, tidak peka mengurusi isi. Gemar membuat organisasi, kurang mampu membuat jaringan. Cenderung memahami segala sesuatu secara simplistis, kurang suka dengan kerumitankecanggihan padahal inilah adanya segala sesuatu itu. Sering berpikir linier tentang sejarah, kurang suka bersusah-susah memahami sejarah dengan rumus dialetika atau sinergis. Enggan melihat diri sebagai tumpuan perubahan, sebaliknya cenderung berharap, perubahan dari atas/para pemimpin.

Senang membuat program, kurang mampu membuat agenda. Cenderung memahami dan menjalani segala sesuatu secara parsial, tidak secara integral (kaffah). Senang bergumul dengan soal-soal jangka pendek, kurang telaten mengurusi agenda jangka panjang. Terusmenerus "menyerang musuh" di markas besarnya, abai pada prioritas pertama "menyerang musuh" pada gudang amunisinya. Kerap menjadikan politik sebagai tujuan, bukan sebagai alat. Senang mengandalkan dan memobilisasi orang banyak atau massa untuk segala sesuatu, abai pada fakta bahwa perubahan besar dalam sejarah selalu digarap pertama-tama oleh creative minority.

Senang berpikir bagaimana memakmurkan masjid, kurang giat dan serius berpikir bagaimana memakmurkan jamaah masjid. Senang menghapalkan tujuan sambil mengabaikan pentingnya metode, tidak berusaha memahami dengan baik tujuan itu sambil terus menerus mengasah metode. Senang merebut masa depan dengan meninggalkan hari ini atau merebut hari ini tanpa kerangka masa depan, bukannya merebut masa depan dengan mencoba merebut hari ini. Sangat pandai membongkar-bongkar, kurang pandai membongkar pasang. Sangat cepat dan gegabah merumuskan musuh baru (dan lama), sangat lamban dan enggan merangkul kawan baru.

Gegap gempita di wilayah ritual, senyap di wilayah politik dan sosial. Selalu ingin cepat meraih hasil, melupakan keharusan untuk bersabar. Senang menawarkan program revolusioner tapi abai membangun struktur revolusi. Selalu berusaha membuat politik hitam putih, bukan penuh warna tak terhingga, dan sangat pandai melihat kesalahan pada orang lain, kurang suka melakukan intropeksi.

Peradaban Islam adalah sesuatu yang sangat tak mungkin dibayangkan tanpa kehadiran variable ekonomi. Posisi politik umat Islam Indonesia saat ini sangat tak menguntungkan untuk optimalisasi kapasitas dan kapabilitasnya untuk membangun peradaban yang maju, inklusif dan bersaing.

Menurut Sensus Penduduk Tahun 2010 komposisi penduduk Indonesia berdasarkan agama yang dipeluk menunjukkan umat Islam sebagai mayoritas dengan angka mendekati $90 \%$ disusul Protestan dan Katholik. Tetapi kondisinya tidaklah seunggul jumlahnya. Inilah yang kerap disebut technical minority, numerical mayority. Meski menang secara jumlah, namun kalah secara teknis dan kualitas. 
Dalam tataran keumatan gejala kemiskinan kepemimpinan dan keteladanan identik dengan kondisi secara umum bahwa umat Islam yang berbeda-beda organisasi, madzhab dan afiliasi partai politik tetap berusaha untuk hidup dalam suasana damai dan semangat persaudaraan yang dewasa. Kerukunan internal umat Islam cukup baik dan kondusif. Mereka sangat toleran, dan dengan kadar luar biasa tolerannya itulah ia kerap menjadi sasaran perlakuan tidak adil. Meskipun demikian, di dalam tubuh umat Islam tak dinafikan terdapat gejala meningkatnya ashabiyyah, orientasi mobilisasi umat untuk kepentingan politik jangka pendek dan melemahnya solidaritas sesama. Gejala-gejala tersebut terjadi karena kemiskinan kepemimpinan umat yang ditandai oleh terbatasnya jumlah pemimpin yang berkarakter profetik, visioner, menjadi teladan, dan mampu mempersatukan umat (shiddiq, tabligh, amanah, dan fathanah).

Komodifikasi (komoditi: komersialisasi) agama adalah hal-hal tercela namun kerap terjadi. Sebetulnya umat Islam Indonesia memiliki ketaatan yang tinggi dalam melaksanakan shalat, membayar zakat, berpuasa pada bulan Ramadhan dan menunaikan ibadah haji (juga berkalikali umrah). Selain itu, kegiatan keislaman seperti pengajian, dzikir, ziarah, dan festival keagamaan juga cukup semarak. Walaupun demikian, kesemarakan beragama ternyata belum diikuti oleh keluasan pemahaman, kedalaman penghayatan, dan kerahmatan pengamalan Islam. Penulis tidak tahu apakah pembaca tak melihat fakta-fakta deviasi keberagamaan dalam bentuk komodifikasi agama untuk kepentingan sangat jangka pendek sebagai sesuatu yang tak bisa dipertanggungjawabkan karena tak member arah perubahan struktural maupun kultural.

Di lain pihak kondisi umat Islam Indonesia saat ini masih terbelenggu konservatifisme agama. Kecenderungan mengembalikan praktik pada tradisi lampau dengan menolak kemajuan yang potensial menimbulkan beberapa masalah keagamaan dan kebangsaan seperti kekeliruan identifikasi Islam dengan Arab, kekakuan beragama yang menganggap diri dan kelompoknya paling benar serta ekslusivisme. Harap dicatat, iman pun setiap saat wajib diperbaharui dan ditegarkan menghadapi perubahan.

Soeharto sangat monumental dengan trilogi pembangunannya berisi stabilitas, pertumbuhan dan pemerataan dengan dibarengi prinsip delapan jalur pemerataan. Namun hingga memasuki tahun-tahun terakhir masa kejayaan rezim ketaat-asasan tidak ditemukan. Pembangunan yang berorientasi Indonesia sentris, bukan Jawa sentris, adalah warna kebijakan yang kelihatannya menjadi prinsip penting dalam pemerintahan Presiden Joko Widodo dengan penekanan pada pembangunan pulau-pulau terluar, infrastruktur dan keterhubungan (connectivity).

Sembari berharap ada perubahan besar untuk pemerataan, beberapa hal penting dikemukakan sebagai berikut: Pertama, kesenjangan adalah masalah paling serius di Indonesia saat ini yang dalam jangka waktu yang tak begitu memberi kesempatan kelihatnnya akan menjadi pemicu untuk berbagai instabilitas. Masalah-masalah yang selama bertahun-tahun belakangan ini menyita perhatian publik seperti pemberantasan korupsi adalah masalah yang kemudian akan menemukan relevansinya tersendiri terutama jika gerakan ini diarahkan secara tepat berdasarkan peta korupsional yang objektif. Lagi pula susahlah mempertanggungjawabkan secara moral dan politik arah pemberantaan korupsi yang diarahkan kepada ranah-ranah kecil dengan tak mau tahu kesenjangan besar yang disebabkan oleh mega korupsi nasional berusia langgeng. Mestinya KPK faham ini. 
Sebagai perbandingan, Anti-Corruption Conference (IAAC) ke 12 yang mengusung tema towards a fairer world: Why is corruption still blocking the way? berseru agar pemerintahan di mana saja jangan beruas diri atas apa yang dicapainya dalam hal perang terhadap korupsi, mereka harus tampil dalam gegas kemauan politik untuk tindakan nyata, dan rakyat jangan disepelekan saat meminta accountability.

Kedua, ekonomi Pancasila sebagaimana pernah dikemukakan oleh Presiden Joko Widodo sangat perlu dirumuskan sehingga aspek ontologis, epistemologis, dan aksiologisnya terandalkan dan yang lebih penting Pancasila itu tak lagi hanya disebut-sebut untuk kepentingan klaim legitimasi belaka. Disadari hal itu tidak mudah. Sebagai perbandingan ekonomi Islam yang lebih lazim disebut sebagai ekonomi syariah bahkan sudah jauh lebih maju dilihat dari aspek ontologis, epistemologis dan aksiologisnya.

Ketiga, menurut konstitusi Negara wajib hadir untuk segenap tumpah darah Indonesia yang oleh karena itu determinan utama membangun negeri bukanlah variable-variable perikatan atau kerjasama internasional dan bilateral lainnya.

Keempat, melihat ancaman ke depan, kebijakan yang didasarkan pada prinsip positive discrimination sangat penting dilakukan. Penulis mengapresiasi gagasan-gagasaan serius dari para pemikir kritis seperti Sri-Bintang Pamungkas yang menyarankan jalan satu-satunya ialah kembali ke UUD 1945 yang asli.

Dengan keadaan ekonomi yang umumnya lemah dan secara politik mengalami marginalisasi serius, sebetulnya sukarlah membayangkan kebangunan peradaban Islam di Indonesia ke depan. Karena itu tindakan positive discrimination, sebagaimana diprogramkan Perdana Menteri Mohd Natsir dengan politik Ekonomi Benteng (1950-1957), kiranya sangat relevan memperbaiki keadaan buruk ini ( J. Thomas Lindblad, The Importance of Indonesianisasi during the Transition from the 1930s to the 1960s, 2002). Sebagai perbandingan sejak tahun 1970-an Malaysia juga melakukan hal yang sama dengan nama New Economic Policy yang secara eksplisit memberi porsi proporsional bagi pribumi untuk beroleh akses dan kepemihakan secara struktural melalui kebijakan pemerintah (Durrishah Idrus, New Economic Policy and the Birth of Malaysia's Own Industrial Relations System, 2013).

Sesuatu perlu diwaspadai, yakni kisah-kisah seperti terjadi di berbagai Negara tetangga akibat invasi ekonomi Negara pemodal khususnya China. Penulis yakin kisah tragis (sebutlah apartheid di Afrika Selatan) yang hancur luluh diakibatkan ketidak-adilan yang mula-mula dilakukan dengan praktik shadow state dan shadow government (Dan Smoot, 1913; William Guy Carr, 1953; Carroll Quigley, 1966; Gary Allen, 1971; Des Griffin, 1976; David Icke, 2011; Gardell, 2003; G. Edward Griffin, 2015; Roig-Franzia, 2016; dan lain-lain). Fenomena ini, menurut IAAC ke 12 tahun 2016 memiliki gejala terpenting yakni adanya sejumlah kelompok di luar pemerintah (termasuk lembaga keuangan internasional) yang memberikan tekanan besar pada struktur negara (berkembang atau yang melemah) dan membentuk inti dari metode pemerintahan yang kurang lebih sejalan dengan struktur pemerintahan formal.

Mengacu kepada studi Berit Bliesemann de Guevara (Potenkim State, 2009), ini tidak perlu sama sekali terjadi di Indonesia, kawan.

Penulis dosen FISIP UMSU. Koordinator Umum Pengembangan Basis Sosial Inisiatif \& Swadaya ('nBASIS). 